\title{
Influence of Selected Socio-Economic Factors on Crop Productivity under Irrigated Agriculture among Kimira-Oluch Smallholder Farmers of Homa Bay County, Kenya
}

\author{
Samson M. Makone ${ }^{1 *}$, David K. Bunyatta ${ }^{1,}$ Samson N. Maobe ${ }^{2}$, Evans A. Basweti $^{2}$ \\ ${ }^{1}$ Department of Agricultural Education and Extension, Kisii University, Kenya \\ ${ }^{2}$ School of Agriculture and Natural Resource Management, Kisii University, Kenya
}

\begin{abstract}
Irrigation technology plays a critical role in enhancing agricultural productivity globally. For the last ten years, the availability of water for irrigation has been rapidly declining yet the demand for water for irrigation has been on arise. The introduction of irrigation technologies as immediate interventions for crop productivity has proved to be effective in many countries and most likely has changed the phenomenon to a more reliable and sustainable agricultural production. Despite many efforts by the Kenyan government to improve the country's agricultural sector, still there is low crop productivity due to the continued practice of rainfed agriculture. The main objective of this study was to determine the influence of selected socio-economic factors that is the attitude towards the introduction of irrigation intervention, Irrigation technologies, Gender participation, Age of the participant, Household income, and Level of education on crop productivity among Kimira-Oluch smallholder farmers in Homa Bay County, Kenya. A survey methodology with an Ex-post facto research design was used with a sampling frame consisting of 340 smallholders. Data were collected through interview schedules administered to participants in irrigated agriculture and Nonparticipants (rainfed agriculture). Inferential statistics used involves multiple regression analysis and two-way ANOVA. The hypothesis was tested at a 5\% level of significance and the results revealed an absolute value of correlation coefficient of 0.823 which indicates that there is a high correlation between the crop productivity and selected socio-economic factors that is (ATT, $I R T, G P, H I, A R$ and ELR). The findings further revealed that $R 2=0.714$ of the proportionate variation of the model an indication that, the selected socio-economic factors can predict $71.4 \%$ of crop productivity and the other variables not included in the model can only predict $29.6 \%$ of productivity. By using analysis of variance (ANOVA) the findings revealed that the regression model predicts that there is a significant improvement in crop productivity and the farming system as well. This was revealed by the $F$ ratio of 71.83 indicating a significant relationship at a $p$-value of $=0.000$. The model will be of greater use in determining the influence of socio-economic factors on crop productivity in other regions without necessary undergoing the full research processes thus reducing the research expenses by almost half.
\end{abstract}

Key Words: Socio-Economic; Crop Productivity; Irrigated Agriculture; Irrigation Technologies; Smallholder Farmers; Kimira-Oluch.

\section{INTRODUCTION}

Irrigation technology plays a pivotal role in enhancing agricultural productivity globally. For the last ten years the availability of water for irrigation has been rapidly declining yet the demand for water access for irrigation has been on arise (Upadhyay, 2004). According to FAO, (2000), irrigated agricultural lands have increased tremendously by almost $2.4 \%$ in the 1970 s to $1.4 \%$ during the 1980s and late 1990s worldwide; it is projection is expected to rise further by over $0.4 \%$ per year for the next 34 years. This therefore means that the irrigation sector utilizes a large share of world's water and also the demand for irrigation water will proceed to increase in the years to come. According to CSD, (1997), the global population for the last four decades has doubled and water consumption for industrial and domestic purposes has tripled during the same period thus, increasing the competition on water resources among the users.

The role of irrigation in enhancing crop productivity is not only important but also well recognized in most countries. Over $21 \%$ of arable lands are irrigated and these croplands contributes only one-third of the world's food supply (FAO, 2016). The continued 
rise of irrigated area and the technological advancement brought along with the Green Revolution which enabled Asia to attain food self-sufficiency because of modernization of irrigation schemes as a water shortage interventions, an important part of achieving food security (FAO, 1992). The rationale behind irrigation interventions therefore, is to increase food supply in the study area and beyond. The primary aim of irrigation systems is to supply right amount of water at the right time which can be determined through computing the balance of water in the soil and in the root zone on a daily basis, the depth and the timing also is important in future irrigations planning (Karina \& Mwaniki, 2011), hence Kimira-Oluch is one of such irrigation scheme in Kenya.

Selected socio-economic characteristics under focus that might influence irrigation technologies adoption directly or indirectly in Kimira-Oluch include: attitude, Irrigation technologies, gender, age, education, and income levels are the major factors affecting irrigation systems and water utilization. It is evident that, different role played by family members relates to different gender, that is role played by men, women and children differ in the family set up. The current study therefore want to determine to what extent socio-economic factors influence either positively or negatively to irrigation technologies. According to Calatrava-Leyvaet al., (2005), the importance of studying these factors is because they aid in decision making whether to adopt irrigated agricultural technologies and also have great impact on water usage in irrigation farming. The demand of water is directly proportional to the behaviors of the consumers of that water in the community, the more the activity engaged by the community that depends on the water, the more the water demands, thus increased water competition amongst them (Mendola, 2005). Moreover, social behavior, cultural and technical factors affect water usage through, employing and consistence use of irrigation technology adopted by farmers.

\subsection{Attitude Factor}

Adoption of a new technology, including irrigation technologies is a complex process to most farmers. Many socio-economic factors contribute to household decisions making thus affecting adoption processes. The current study sought to determine the influence of farmers' attitudes towards irrigation technologies and its impact on crop productivity. According to Kulshreshatha\& Brown (1993), in their study they suggested that negative attitude with respect to social and economics of irrigation systems and others factors related to its detrimental impacts on environmental quality, especially through soil salinity, may be significant deterrents for irrigation technologies adoption.

\subsection{Irrigation Technologies}

Irrigation technologies has demonstrated beyond reasonable doubt to be the most reliable and viable technologies in changing the livelihoods of the rural smallholder farmers in developing countries (Daniel, 2015). According to Burrow (1987), the returns from irrigated agriculture even from small plots are significantly exceeding same size of land in rainfed agriculture. In most developing countries, the irrigation development were considered to be more viable in the provision of food security, increase crop yield, improved employment opportunity to poor farmers and also to reduce unpredictable and erratic rainfall. Gor Cornist (1999) in his study indicated that, some irrigation technologies have come out to be the solely provider for income in the sense that, it empower farmers to earn an increased income which enables them to acquire some of their basic wants. Kundlande et al., (1994), in their study found out that, food production from irrigated agriculture serve as the major source of farmers wealth creation to the a larger extent that it is the fundamental for economic development and growth in most developing countries.

\subsection{Gender Factor}

The researcher believed that gender division in the family would significantly determine the roles played by the households, owing to the fact that engagement in any activity vary based on the sex of the respondents. According to IFAD, (2012b), Men and women have distinct priorities on water utilization, while majority of women would prefer to use water for more purposes other than irrigation such as in domestic use and irrigate home gardening especially vegetables as the men counterpart prefer to utilize irrigation water for irrigating the more yielding cash crops. Gender is believed to influence the type and simplicity of irrigation systems to be employed. Women would prefer simple technology such as bucket contrary to their male counterparts who tend to use more sophisticated irrigation technologies (NSSP, 2010). The gender analysis of Kimira-Oluch was analyzed and found that, about $60 \%$ Male and $40 \%$ Women.

\subsection{Age Factor}

Farmers' age play a critical role in technology application and also aid in decision making in the simplicity of irrigation technology to be implemented (Ramirez et al., 2008). In most cases, age as been considered a key factor when it comes to quality of decision and farmer's attitude towards adapting the new irrigation technologies and water use (Ahmed et al., 2012). According to Owilla (2010), in his study he noted that, there negative relationship between farmers' age and water utilization in Mwea irrigation scheme, where the old farmers tend to have less access to irrigation water as compared to younger people. A study by Adeoti (2009) reported that, negative association between irrigation technology and age of farmers' effect on the water usage for irrigation farming. Therefore, the age of the farmer is highly linked to less water used thus more efficiency. In regard to Kimira- 
Oluch irrigation scheme, half of the farming population fall under the age bracket of 36-55 years which is driving force in farming community. The current research has shown that youth do not regard farming as economic empowerment therefore they tend to look down upon any activities that go with manual work.

\subsection{Education Factor}

Education equips the farmers with knowledge and skills to enable them to manage and utilize water effectively, in addition, to make them to stand at better position to make decisive decision on the type of irrigation technology to adopt. The more educated farmers are the better he/she will comprehend any technical knowledge and make a meaningful contribution towards water and irrigation system management (Rockaway et al., 2011). In addition, the level of education of the farmer has positive impact on irrigation water utilization efficiency in the farm, this therefore, promotes farmers adoption to cheaper and affordable irrigation technologies (Chebil et al., 2012). According to Amao \& Awoyemi (2008), education open farmers mind and increases the required agricultural skills and knowledge of the new technology package thus better understanding on how to apply them.

Waithaka et al. (2007) conducted a research in Vihiga sub-county, Kenya and noted that by increasing the educational level of the household head enable the farmer to use the inputs such as fertilizer, seeds and agro-chemicals per the recommendation thus better yields and better irrigation system management. The same sediments were echoed by Ariga et al, (2009) who asserted that the farmers' educational background has significant effect of technology use. This is due to different irrigation technology requires different mode of application to specific crops; however some farmers who don't know how to apply the technology end up misuses irrigation water. Also, different type requires different application mode, rate of application and timing of application with education therefore errors that might be committed will be minimized. The situation in Kimira-Oluch education analysis were so diverse as, about $39.7 \%$ of the farmers had secondary education level followed by primary education level at $24.1 \%$ where as $22.6 \%$ stated having attained Middle level colleges and those with University academic qualification and none educated/illiterate represented by $10 \%$ and $3.2 \%$ respectively.

\subsection{Income Factor}

Farmer's income levels play a role in determining the kind of irrigation technology to be applied by the farmers. Farmers with high income potential would prefer a more sophisticated and expensive technology whereas farmers with low income potential may opt for a cheaper irrigation technology. According to Jansen and Schulz (2006), farmer's income level is the major determinant of water usage and thus demands for irrigation technology to control its use. Moreover, farmers with less income levels who entirely depend on farming as their main livelihood appear to utilize water more efficiently. In other word, low income farmers use relatively little water per unit of area for irrigation purposes. Hence, positive relationship between technology adoption, irrigation water utilization and income of farmers (Adeoti, 2009)

Briggeman (2011) in his research indicated that, income from farming alone is not adequate enough for most small scale farmers to service their irrigation systems. Engaging in off-farm activities brings extra wages and thus become their main source of income. In 2008, about $90 \%$ of household farm income almost all of them come from off-farm activities. To expand income streams, farm households must solely depend on off-farm employment. Large scale farms depends less on off-farm income since they fetch a lot of income almost ten times more than small scale farms. According to Janvry, Sadoulet, \& Zhu, (2005), engaging in off-farm activities has proved to have a positive impact on households' agricultural activities and have shown a significant impact on rural economies. In a study in China by Janvry et al. (2005) indicated that despite of tremendous growth of non-farm activities in the country, a lot of changes have take effect in rural community since the introduction of the irrigation technologies. While, farming still being the sole source of household income for local people and off-farm income contributes significant more in total income. The respect to Kimira-Oluch irrigation scheme, the household monthly income accrue from farming, revealed that, $68.5 \%$ of the respondents earned 10,000 and below, followed by household monthly income earner between 10,001-50,000 represent by $28.2 \%$ and those with monthly income between 90,001 were represented by $0.9 \%$ and finally between 90,001 and 130,000 were $2.4 \%$. This means that, farmers of Kimira-Oluch with the current state of financial status are unable to meet their financial obligation that requires more capital for productive activities such as buying agricultural inputs such hire of farm implement or purchase them as well purchase of fertilizers and seeds.

The main objective of this study was to determine the influence of selected socio-economic factors (attitude towards introduction of irrigation intervention, Irrigation technologies, gender participation, age of the participant, household income and level of education) on crop productivity among Kimira-Oluch smallholder farmers in Homa Bay County, Kenya. The hypothesis testing was that, selected socio-economic factors do not have statistically significant influence on crop productivity. 


\section{METHODS AND MATERIALS}

\subsection{Study Area}

This research was conducted in Oluch scheme in Homa Bay sub-county and Kimira scheme in Rachuonyo sub-county in Homa Bay county, Kenya situated between latitudes and longitudes of $0^{\circ} 20^{\prime} \mathrm{S}$ and $0^{\circ} 30^{\prime} \mathrm{S}$ and $34^{\circ} 30^{\prime} \mathrm{E}$ and $34^{\circ} 39^{\prime} \mathrm{E}$ respectively along the shore side of Lake Victoria's Winam Gulf in Kimira irrigation scheme as shown in Figure 1. The scheme utilizes only 808 ha for irrigation systems out of a total area of 1,790 ha whilst Oluch irrigation scheme utilizes only 666 ha for irrigation systems out of a total area of 1,308 ha.

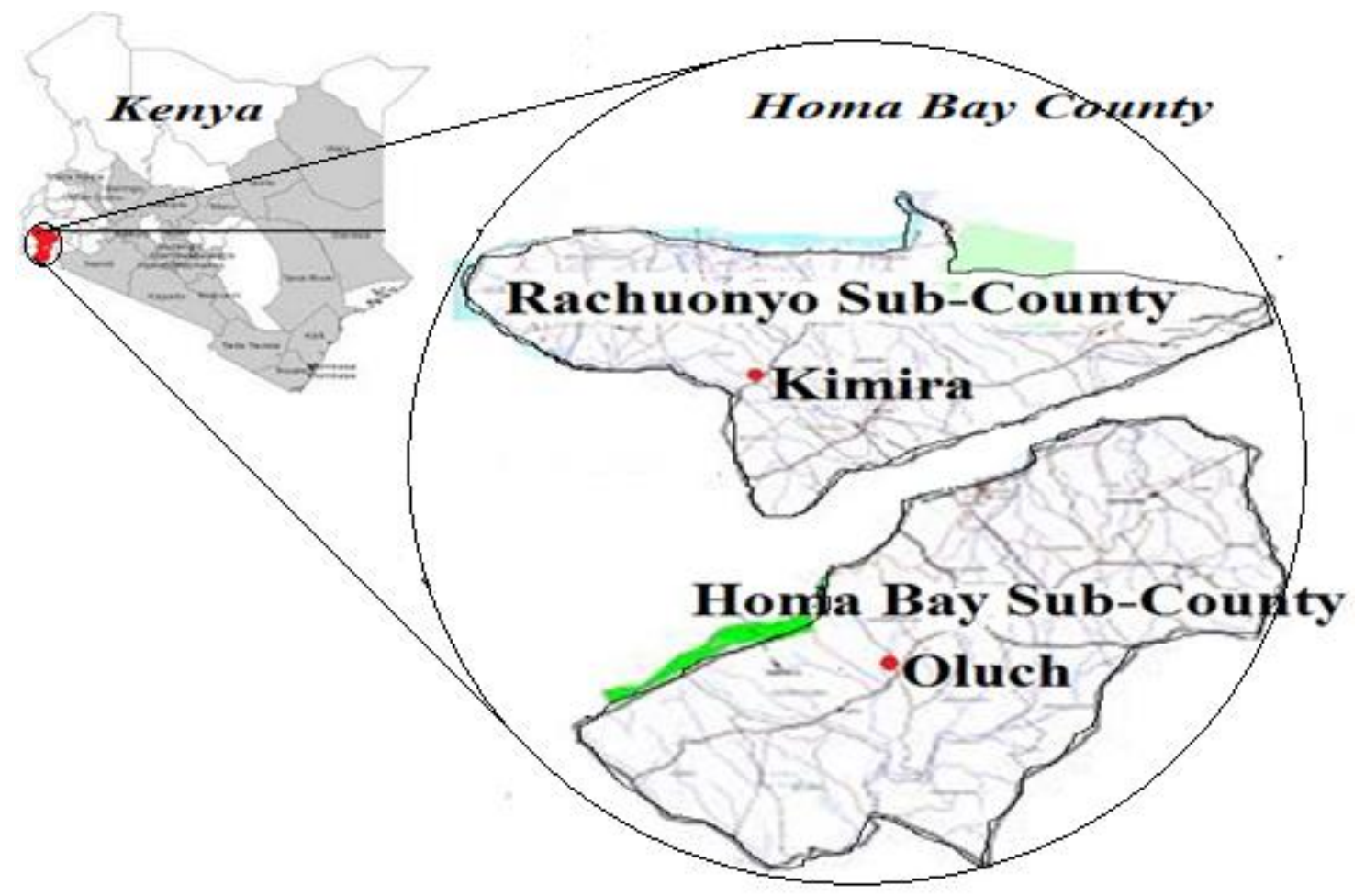

Figure 1: The Map of Kenya Showing the study area in Homa Bay County, Kimira and Oluch Scheme

\subsection{Research Design}

This study employed ex-post facto research design; the choice of this research design was adopted because it allows the investigator (s) to conduct the study after the fact has occurred without necessarily interfering with the variables (Ellis-O'Quinn, 2012). Ex-post facto is ideal especially when the variables being studied are not manipulated, but studied in their natural context (Wiersma, (2009). According to Kothari, (2012) he argues that Ex-post facto research design may be used to assess relationships between previous and past events.

\subsection{Target Population}

The study targeted individual smallholder farmers who crop identified crops, the extension officers and crop marketing groups. The estimated targeted households was 1,616 in Karachuonyo (Kimira) and 1,308 in Homa Bay town (Oluch) respectively with about 40 percent of the households being headed by women, based on "clan elders" which was crucial for researcher for easy mobilization of the resources and easy conflict resolution (KNBS, KOSFIP, 2006). The targeted individual crop farmers was subjected for face to face interviews using a semi structured schedules and also the extension service providers from the two sub counties was purposely selected. Both qualitative and quantitative data was used to analyze the data. 


\subsection{Sampling Techniques and Sample Size Determination}

Simple random and purposive sampling methods were employed. Simple random sampling was used to select irrigation participant and non-irrigation participants. The irrigation participants were selected based on irrigation water utilization. Here the researcher was guided into specific farmers by following the secondary drainage from the main primary canal whereas the nonparticipants were selected using the same method however, here the researcher targeted farmers without irrigation channel in their plots despite having access to water. Purposive sampling was used to select agricultural extension officers, since the agricultural extension officers were known, they were purposively chosen on the basis of who meets the purpose of the study at its best. The study therefore applied fisher formula (Mugenda \& Mugenda, 2003) to give a representative sample size of 340 respondents which was distributed based on the area size Table 1.

Table 1: Sample Size Distribution in Kimira-Oluch Irrigation Scheme

\begin{tabular}{lccccc}
\hline Sub-Counties & $\begin{array}{c}\text { Total Area } \\
\text { (ha) }\end{array}$ & $\begin{array}{c}\text { Total area Under } \\
\text { Irrigation (ha) }\end{array}$ & $\begin{array}{c}\text { Household } \\
\text { Beneficiaries }\end{array}$ & $\begin{array}{c}\text { No. of } \\
\text { Divisions }\end{array}$ & $\begin{array}{c}\text { Desired sample size } \\
\left(\frac{\boldsymbol{x}}{\boldsymbol{N}} \boldsymbol{X} \boldsymbol{n}_{\boldsymbol{f}}\right)\end{array}$ \\
\hline $\begin{array}{l}\text { Rachuonyo (Kimira } \\
\text { scheme) }\end{array}$ & 1,790 & 808 & 1,616 & $4(\mathrm{x})$ & 227 \\
$\begin{array}{l}\text { Homa Bay town } \\
\text { (Oluch scheme) }\end{array}$ & 1,308 & 666 & 1,334 & $2(\mathrm{x})$ & 113 \\
\begin{tabular}{l} 
Totals \\
\hline
\end{tabular} & $\mathbf{3 , 0 9 8}$ & $\mathbf{1 4 7 4}$ & $\mathbf{2 , 9 5 0}$ & $\mathbf{6}(\mathbf{N})$ & $\mathbf{3 4 0}$ \\
\hline
\end{tabular}

Source; KNBS: (Where $\left.\boldsymbol{n}_{\boldsymbol{f}}=\mathbf{3 4 0}\right)$

\subsection{Statistical Analysis}

\subsubsection{Descriptive Statistics}

Descriptive statistics was based on the raw data obtained and the researcher used the information to draw a certain indices from it. It involved cross tabulations of the percentages and frequencies for easy close examine of the variables being investigated.

\subsubsection{Inferential Statistics}

Inferential analysis deals with various tests of significance for testing hypothesis that, selected socio-economic factors do not have statistically significant influence on crop productivity.In this regards, inferential statistics was employed where Analysis of Variance (ANOVA) was used and for the purpose of this particular study, a two-way ANOVA was applied since there was multiple factor under investigation (social-economic factors) on crop productivity (dependent variable) andalso the use multiple linear regression analysis to ascertain the relationship between the variables under study (selected socio-economic factors such as attitude towards introduction of irrigation intervention, gender participation, age of the participants and level of education of the farmers).

\subsubsection{Analytical Model}

The following model was used in analyzing data both descriptively and inferentially using the weighted mean as shown below.

Weighted Mean $=\boldsymbol{\Sigma} \boldsymbol{w}_{i} \boldsymbol{f}_{i} / \boldsymbol{\Sigma} \boldsymbol{f}_{i}$

Where: $=\boldsymbol{w}_{i}$ is the weight and

$=\mathbf{f}_{\mathrm{i}}$ is the frequency. 
The following multiple regression model analysis was used: the first step was to assess the technological impact of the selected crops

$Y=\mathbf{a}_{0}+\beta_{1} X_{1}+\beta_{2} X_{2}+\beta_{3} X_{3}+\beta_{4} X_{4}+\beta_{5} X_{5}+\varepsilon$ Equation 1

\section{Where,}

$\mathbf{Y}=$ is Productivity of selected crop (Dependent Variable)

$\mathbf{a}_{\mathbf{0}}=$ is the constant term;

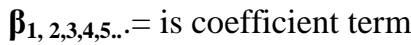

$\mathbf{X}=$ is the independent variables (Socio-Economic factors) term that influence crop productivity.

$\boldsymbol{\varepsilon}=$ is the marginal error usually assumed to be normally distributed.

Independent variables $\mathrm{X}$ (Socio-Economic factors) can be further redefined as:

$\mathbf{X}_{\mathbf{1}}$ =is the linear sensitivity of Attitude towards introduction of irrigation technologies (ATT)

$\mathbf{X}_{\mathbf{2}}=$ is the linear sensitivity of Irrigation technologies (IRT)

$\mathbf{X}_{\mathbf{3}}$ is the linear sensitivity of Gender participation (GP)

$\mathbf{X}={ }_{\mathbf{4}}$ is the linear sensitivity of Age of the respondents (AR).

$\mathbf{X}={ }_{\mathbf{5}}$ is the linear sensitivity of Education level of the respondents (ELR).

Therefore the general multiple regression model was formed as shown in equation 3 below.

$\operatorname{Productivity}(\boldsymbol{Y})=\boldsymbol{a}_{0}+\beta_{1} \mathrm{ATT}+\beta_{2} I R T+\beta_{3} \mathrm{GP}+\beta_{4} A R+\beta_{5} E L R+\boldsymbol{\varepsilon}$

Equation 2

\section{RESULTS}

\subsection{Irrigation Technologies Promoted in Kimira-Oluch Scheme}

Some of the irrigation technologies promoted in the study area include; sprinkle, open gravity, water can, treadle pumps, flood irrigation, canal and pipe conveyance system and motorized pump. However, the level of usage differs depending on the farmer's economic stability and availability. From the findings it is evident that, open gravity canal was mostly used at $63.5 \%$ followed by water can method at $46.8 \%$ and canal and pipe conveyance system at $45.0 \%$. On the other hand the sprinkle irrigation never used by $82.6 \%$ of the respondent as implicated in Table 2 . This imply that, farmers of Kimira and Oluch used the available system as it was installed by the investor since it doesn't require any maintenance costs while the use of sprinkle was minimal since majority of the farmers couldn't afford the pumps and installation costs associated.

Table 2: Irrigation Technologies Promoted in the Area

\begin{tabular}{|c|c|c|c|c|c|c|}
\hline \multirow[b]{2}{*}{ Technologies } & \multicolumn{5}{|c|}{ Level of Usage (\%) } & \multirow[b]{2}{*}{ Rank } \\
\hline & $\begin{array}{c}\text { Never } \\
\text { Used }\end{array}$ & $\begin{array}{c}\text { Rarely } \\
\text { Used }\end{array}$ & $\begin{array}{c}\text { Moderately } \\
\text { Used }\end{array}$ & $\begin{array}{c}\text { Sometimes } \\
\text { Used }\end{array}$ & $\begin{array}{c}\text { Mostly } \\
\text { Used }\end{array}$ & \\
\hline Open gravity canal & 14.4 & 11.2 & 3.5 & 7.4 & 63.5 & 1 \\
\hline Water can method & 17.9 & 10.6 & 8.2 & 16.5 & 46.8 & 2 \\
\hline Canal and pipe conveyance & 13.8 & 4.7 & 21.2 & 15.3 & 45.0 & 3 \\
\hline Motorized pump & 31.2 & 12.4 & 2.9 & 35.0 & 18.5 & 4 \\
\hline Flood irrigation & 26.8 & 42.4 & 12.9 & Nil & 17.9 & 5 \\
\hline Treadle pumps & 21.2 & 5.9 & 36.2 & 34.6 & 2.1 & 6 \\
\hline Sprinkle irrigation & 82.6 & 12.4 & Nil & 4.4 & 0.6 & 7 \\
\hline
\end{tabular}




\subsection{Gender of the Respondents}

The researcher believed that gender division in the family would significantly determine the roles played by the households, owing to the fact that engagement in any activity vary based on the sex of the respondents. Based on this fact the farmers were asked to state their gender for the purpose of categorizing them. Out of 340 respondents who were interviewed, 203 were male which translate to $59.7 \%$ while 137 representing $40.3 \%$ were female as indicated in Table 3 .

Table 3: Gender of the Respondents

\begin{tabular}{lll}
\hline Gender & Frequency & Valid Percent $(\boldsymbol{\%})$ \\
\hline Male & 203 & 59.7 \\
Female & 137 & 40.3 \\
Total & $\mathbf{3 4 0}$ & $\mathbf{1 0 0 . 0}$ \\
\hline
\end{tabular}

\subsection{Age of the Respondents}

The finding of the study as indicated in Table 4 revealed that, 50\% of the respondents fall under the age bracket of 36-55 years, followed by youths of the age bracket of 18-35 years representing 37.4\%, and between the age bracket of 56-69 years and 70 years and above represented by $8.5 \%$ and $4.1 \%$ respectively.

Table 4: Age of the Respondents

\begin{tabular}{lll}
\hline Age bracket & Frequency & Valid Percent (\%) \\
\hline 18-35 years & 127 & 37.4 \\
$36-55$ years & 170 & 50.0 \\
$56-69$ years & 29 & 8.5 \\
Over 70 years & 14 & 4.1 \\
Total & $\mathbf{3 4 0}$ & $\mathbf{1 0 0 . 0}$ \\
\hline
\end{tabular}

\subsection{Educational Level of the Respondents}

The extent to which farmers acquire knowledge would determine their competence in agricultural crop productivity and improved farming systems in general. In the light of such assumption, the respondents were asked to state their academic qualifications as indicated in Table 5. Out of 340 respondents who participated in this study, majority of them had secondary education level at a frequency of 137 representing 39.7\%, followed by primary education level at frequency of 82 representing $24.1 \%$ where as $22.6 \%$ stated having attained Middle level colleges and those with University academic qualification and none educated/illiterate represented by $10 \%$ and $3.2 \%$ respectively. The implication of these findings did not demonstrate substantial education potential, given the fact that just $32.6 \%$ of the respondents had attained middle level colleges and University level of education which are considered as the pool of knowledge to change the farming systems. Addressing the challenges associated with crop productivity therefore would be a big problem since enhanced agricultural output correspond purely with the extent to which farmers adopts to new and modern technologies which in itself, is a function of education.

Table 5: Education Level of the Respondents

\begin{tabular}{lcc}
\hline Education levels & Frequency & Valid Percent (\%) \\
\hline None educated/illiterate & 11 & 3.2 \\
Primary Education & 82 & 24.1 \\
Secondary Education & 135 & 39.7 \\
Middle level colleges & 77 & 22.6 \\
University Education & 34 & 10.0 \\
Any other & 1 & 0.3 \\
Total & $\mathbf{3 4 0}$ & $\mathbf{1 0 0 . 0}$ \\
\hline
\end{tabular}




\section{DISCUSSION}

\subsection{Farmer's Attitude towards the Introduction of Irrigation Technologies (ATT)}

The objective was to assess farmers' attitude towards the introduction of irrigation intervention on crop productivity. In this regard, the respondents were asked to tick the option which best described their assessment of the extent to which they felt farmers' attitude towards introduction of irrigation technologies based on a Likert scale with a scale of 1 for Strongly Disagree, 2 for Disagree, 3 for Undecided, 4 for Agree and 5 for Strongly Agree. The results and analysis were tabulated in Table 6.

This result in Table 6 showed that, all the measures of farmers attitudes towards the introduction of irrigation technologies in Kimira-Oluch scheme had an average weighted mean of 3.5 against the maximum value of 5 this means that farmers' attitude towards introduction of irrigation technologies had an influenced to crop and livestock productivity. On average, about 69.5 (20\%) of the respondents strongly disagreed that the introduction of irrigation technologies had an influence on productivity of crop and livestock, 56.3 (15\%) of the respondents disagreed that the introduction of irrigation technologies had an influence on productivity of crop and livestock, 26.7(9\%) of the respondents had mixed reaction (Undecided) that the introduction of irrigation technologies had an influence on productivity of crop and livestock, 88.7 (24\%) of the respondents agreed that the introduction of irrigation technologies had an influence on productivity of crop and livestock while 125.8 (32\%) of the respondents strongly agreed that the introduction of irrigation technologies had an influence on productivity of crop and livestock. The standard deviation of 0.03 revealed that the variability of the responses was very small indicating that the respondents' responses were close to each other.

This study is in agreement with a study carried out by Muthui, (2015), who indicated that attitude toward adopting new farming technologies had a positive attitude with majority presented by $98 \%$ being the first or among the first to start innovations within a period of 1-2years whereas only $2 \%$ had never employed any new farming technology in their farms for the last 3 years. On the other hand, for non- adopters it was found that only 3\% indicated to be among the first ones to adopt any new farming technology while $25 \%$ indicated to wait for other model farmers to start before making a decision and $72 \%$ of the farmers never adopted new farming technologies or innovations.

Table 6: Farmer's Attitude towards the Introduction of Irrigation Systems

\begin{tabular}{|c|c|c|c|c|c|c|c|c|}
\hline Factor & (1) & (2) & (3) & (4) & (5) & $\Sigma f i$ & Ewifi & $\Sigma w i f i / \Sigma f i$ \\
\hline $\begin{array}{l}\text { I took part in the establishment of irrigation } \\
\text { systems project }\end{array}$ & 108 & - & - & 140 & 92 & 340 & 1128 & 3.3 \\
\hline $\begin{array}{l}\text { Farmers of Kimira-Oluch are embracing the } \\
\text { irrigation technology }\end{array}$ & - & 16 & 73 & 148 & 103 & 340 & 1358 & 4.0 \\
\hline $\begin{array}{l}\text { Farmers were trained on the irrigation systems } \\
\text { matters before introduced to the region }\end{array}$ & 8 & 59 & 26 & 79 & 168 & 340 & 1360 & 4.0 \\
\hline $\begin{array}{l}\text { Farmers were fully involved before the } \\
\text { introduction of irrigation systems }\end{array}$ & 19 & 27 & 17 & 166 & 111 & 340 & 1343 & 4.0 \\
\hline $\begin{array}{l}\text { Lack of proper public participation before } \\
\text { setting up the irrigation project destabilizes the } \\
\text { utilization }\end{array}$ & 86 & 99 & 5 & 30 & 120 & 340 & 1019 & 3.0 \\
\hline $\begin{array}{l}\text { The introduction of irrigation systems is not } \\
\text { embraced by many of us farmers and we feel it } \\
\text { is waste of public resource and out time too }\end{array}$ & 189 & 50 & 54 & 3 & 44 & 340 & 683 & 2.0 \\
\hline $\begin{array}{l}\text { The project has changed the life of many } \\
\text { residents has transformed our area or village }\end{array}$ & 33 & 88 & 26 & - & 193 & 340 & 1252 & 3.7 \\
\hline
\end{tabular}


International Journal of Research in Social Science and Humanities (IJRSS), Vol .1(5), Nov-Dec - 2020

\begin{tabular}{|c|c|c|c|c|c|c|c|c|}
\hline $\begin{array}{l}\text { The irrigation project was brought without our } \\
\text { full knowledge }\end{array}$ & 95 & 54 & 26 & 91 & 74 & 340 & 1015 & 3.0 \\
\hline $\begin{array}{l}\text { Attendance to the extension training meetings } \\
\text { is usually by voluntarily and out of } \\
\text { willingness of the farmers }\end{array}$ & 52 & 30 & 29 & 68 & 161 & 340 & 1276 & 3.8 \\
\hline $\begin{array}{l}\text { Attend community meeting along with my } \\
\text { spouse }\end{array}$ & 96 & 55 & 8 & 60 & 121 & 340 & 1075 & 3.2 \\
\hline $\begin{array}{l}\text { The extension training meetings is well } \\
\text { constituted in terms of gender balance. }\end{array}$ & 49 & 53 & 36 & 102 & 100 & 340 & 1171 & 3.4 \\
\hline $\begin{array}{l}\text { We make our own decision on what to plant or } \\
\text { keep in our farms }\end{array}$ & 29 & 48 & 40 & - & 223 & 340 & 1360 & 4.0 \\
\hline Average (\%) & $\begin{array}{l}69.5 \\
(20)\end{array}$ & $\begin{array}{l}56.3 \\
(15)\end{array}$ & $\begin{array}{l}26.7 \\
(9)\end{array}$ & $\begin{array}{l}88.7 \\
(24)\end{array}$ & $\begin{array}{l}125.8 \\
(32)\end{array}$ & 4080 & 14040 & 3.5 \\
\hline Standard Deviation & & & & & & & & $\mathbf{0 . 0 3}$ \\
\hline
\end{tabular}

KEY: 1 =Strongly Disagree, $2=$ Disagree, $3=$ Undecided, $4=$ Agree and $5=$ Strongly Agree. 
In order to determine the farmer's attitude toward the introduction of the irrigation technologies, a five-scale likert was used with a series of question given to the farmers to indicate the level of agreement to those statements as shown in Table 7. The findings indicated that majority of the farmers had positive attitude towards the project because of its benefits to the society. For instance when the farmers were asked "if they took part in the establishment of irrigation system" about $67.7 \%$ agreed to the statement while $30.3 \%$ disagreed to that statement that they didn't took part in the establishment of irrigation technologies. The implication of this is that, the attitude of the farmers was for the project. However when they were asked negation statement that "The introduction of irrigation systems is not embraced by many of us farmers and we feel it is waste of public resource and out time too" about $55.6 \%$ of the respondents strongly disagreed to the statement to means that farmers embraced the irrigation technologies. Even though about $48.6 \%$ of the respondents agreed that "the irrigation project was brought without their full knowledge", this implied that, adoption process took some time for them to accept the system after realizing their benefits. Generally, the attitude of the farmers can be interpreted and determine based on the response of the farmers to a statement given to them as shown in Table 7.

Table 7: Level of Agreement of Farmers' Attitude toward Introduction of Irrigation Technologies

\begin{tabular}{|c|c|c|c|c|c|}
\hline \multirow[b]{2}{*}{ STATEMENTS } & \multicolumn{5}{|c|}{ Level of Agreement in \% } \\
\hline & $\begin{array}{l}\text { Strongly } \\
\text { Disagree }\end{array}$ & Disagree & Undecided & Agree & $\begin{array}{l}\text { Strongly } \\
\text { Agree }\end{array}$ \\
\hline I took part in the establishment of irrigation systems project & 30.3 & - & - & 42.6 & 27.1 \\
\hline Farmers of Kimira-Oluch are embracing the irrigation technology & - & 4.7 & 21.5 & 43.5 & 30.3 \\
\hline Farmers were trained on the irrigation systems matters before introduced to the region & 2.4 & 17.4 & 7.6 & 23.2 & 49.4 \\
\hline Farmers were fully involved before the introduction of irrigation systems & 5.6 & 7.9 & 5.1 & 48.8 & 32.6 \\
\hline $\begin{array}{l}\text { Lack of proper public participation before setting up the irrigation project destabilizes the } \\
\text { utilization }\end{array}$ & 25.3 & 29.1 & 1.5 & 8.8 & 35.3 \\
\hline $\begin{array}{l}\text { The introduction of irrigation systems is not embraced by many of us farmers and we feel it is } \\
\text { waste of public resource and out time too }\end{array}$ & 55.6 & 14.7 & 15.9 & 0.9 & 12.9 \\
\hline The project has changed the life of many residents has transformed our area or village & 9.7 & 25.9 & 7.6 & - & 56.8 \\
\hline The irrigation project was brought without our full knowledge & 27.9 & 15.9 & 7.6 & 26.8 & 21.8 \\
\hline $\begin{array}{l}\text { Attendance to the extension training meetings is usually by voluntarily and out of willingness of } \\
\text { the farmers }\end{array}$ & 15.3 & 8.8 & 8.5 & 20.0 & 47.4 \\
\hline Attend community meeting along with my spouse & 28.2 & 16.2 & 2.4 & 17.6 & 35.6 \\
\hline The extension training meetings is well constituted in terms of gender balance. & 14.4 & 15.6 & 10.6 & 30.0 & 29.4 \\
\hline We make our own decision on what to plant or keep in our farms & 8.5 & 14.1 & - & 11.8 & 65.6 \\
\hline
\end{tabular}




\subsubsection{Influence of Irrigation Technologies on Crop Productivity (IRT)}

The objective was to assess the influence of irrigation technologies on crop productivity. In this regard, the respondents were asked to tick the option which best described their assessment of irrigation technology based on a Likert scale with a scale of 1 for never used, 2 for Sometimes used, 3 for Moderately used, 4 for rarely used and 5 for Mostly used. The results and analysis were tabulated in Table 8 .

This result in Table 8 revealed that, all the measures of irrigation technology had an average weighted mean of 3.0 against the maximum value of 5 which means that the idea of irrigation technology was noble idea that had a significant impact to crop and livestock productivity. On average, about 101 (29.6\%) of the respondents indicated that they never used irrigation technologies to boost agricultural productivity, $48.6(12.3 \%)$ of the respondents said that sometimes they use irrigation technologies to enhance their farming systems, 49.0 (13.4\%) of the respondents indicate moderate use of irrigation technologies, $61.0(16.9 \%)$ of the respondents said that they rarely use irrigation technologies to enhance their crop productivity and farming systems in general whereas, about 94.4 (27.8\%) of the respondents said that they mostly use irrigation technologies to enhance their crop and livestock productivity and farming systems. The standard deviation of 1.7 revealed that the variability of the responses were close to each other.

Table 8: Influence on Irrigation Technologies on Crop Productivity

\begin{tabular}{|c|c|c|c|c|c|c|c|c|}
\hline Factor & (1) & (2) & (3) & (4) & (5) & $\Sigma f_{i}$ & $\Sigma w_{i} f_{i}$ & $\Sigma w_{i} f_{i} / \Sigma f_{i}$ \\
\hline Sprinkle irrigation technology & 281 & 42 & - & 15 & 2 & 340 & 435 & 1.3 \\
\hline Open gravity canal system technology & 49 & 38 & 12 & 25 & 216 & 340 & 1341 & 3.9 \\
\hline Watering can technology & 61 & 36 & 28 & 56 & 159 & 340 & 1236 & 3.6 \\
\hline Treadle pumps & 72 & 20 & 123 & 118 & 7 & 340 & 988 & 2.9 \\
\hline Flood irrigation technology & 91 & 146 & - & 42 & 61 & 340 & 856 & 2.5 \\
\hline Canal and pipe conveyance system & 47 & 16 & 72 & 52 & 153 & 340 & 1268 & 3.7 \\
\hline Motorized pumps technology & 106 & 42 & 10 & 119 & 63 & 340 & 1011 & 3.0 \\
\hline Average (\%) & $\begin{array}{l}101.0 \\
(29.6)\end{array}$ & $\begin{array}{c}48.6 \\
(12.3)\end{array}$ & $\begin{array}{c}49.0 \\
(13.4)\end{array}$ & $\begin{array}{c}61.0 \\
(16.9)\end{array}$ & $\begin{array}{c}94.4 \\
(27.8)\end{array}$ & 2380 & 7135 & 3.0 \\
\hline Standard Deviation & & & & & & & & 1.7 \\
\hline
\end{tabular}

\subsubsection{Influence of Gender Participation on Crop productivity (GP)}

Gender of the respondents determines the roles played by the households, owing to the fact that engagement in any activity vary based on the sex. Based on this fact, different crop is influenced by gender in terms of productivity. The findings of this study revealed that, Maize, Rice and Kale differ in production with gender. For instance, maize is more produced by male than female at standard deviation of 4.546 and 86.582 respectively, whereas rice is more produced by male than female at standard deviation of 2.488 and 82.925 respectively, while kale is more produced by male than female at standard deviation of 7.046 and 120.287 respectively. This simply means the smaller the standard deviation, the more the farmers engaged in that activity and the larger the standard deviation, the less farmers engaging in that activity as indicated in Table 9. 
International Journal of Research in Social Science and Humanities (IJRSS), Vol .1(5), Nov-Dec - 2020

Table 9: Influence of Gender Participation on Crop productivity

\begin{tabular}{lllll}
\hline Gender & & Maize Productivity & Rice Productivity & Kales Productivity \\
\hline Male & Mean & 2.36 & 1.09 & 2.08 \\
& $\mathrm{~N}$ & 203 & 203 & 203 \\
& Std. Deviation & $\mathbf{4 . 5 4 6}$ & $\mathbf{2 . 4 8 8}$ & $\mathbf{7 . 0 4 6}$ \\
\hline Female & Mean & 11.28 & 11.43 & 15.39 \\
& $\mathrm{~N}$ & 137 & 137 & 137 \\
& Std. Deviation & $\mathbf{8 6 . 5 8 2}$ & $\mathbf{8 2 . 9 2 5}$ & $\mathbf{1 2 0 . 2 8 7}$ \\
\hline Total & Mean & 5.95 & 5.25 & 7.44 \\
& $\mathrm{~N}$ & 340 & 340 & 340 \\
& Std. Deviation & $\mathbf{5 5 . 1 2 7}$ & $\mathbf{5 2 . 8 0 4}$ & $\mathbf{7 6 . 6 6 1}$ \\
\hline Average Std. Deviation & & & \multicolumn{2}{|c}{}
\end{tabular}

\subsubsection{Influence of Household Income on Crop productivity (HI)}

The household income levels have been used in determining the influence of crop productivity of the farmers. It's believed that farmers with stable flow of income are likely to afford any expensive agro-services to improve their crop production. Also wealthier farmers are likely to attend seminar meetings, agricultural field day and workshops presided over either by the Ministry or Non-Government Organization and get the necessary skills and knowledge for better crop management. In that regards the income level of the farmers, data were analyzed inferentially against crop productivity and their standard deviation determined as tabulated in Table 10.

Table 10: Household Monthly Income Levels.

\begin{tabular}{lllll}
\hline Total Monthly Income & & Maize Productivity & Rice Productivity & Kales Productivity \\
\hline 10,000 and Below & Mean & 8.27 & 6.88 & 10.41 \\
& $\mathrm{~N}$ & 233 & 233 & 233 \\
& Std. Deviation & $\mathbf{6 6 . 5 0 6}$ & $\mathbf{6 3 . 7 4 4}$ & $\mathbf{9 2 . 5 1 4}$ \\
\hline $10,001-50,000$ & Mean & 0.76 & 1.91 & 1.08 \\
& $\mathrm{~N}$ & 96 & 96 & 96 \\
& Std. Deviation & $\mathbf{0 . 7 7 4}$ & $\mathbf{2 . 4 0 6}$ & $\mathbf{1 . 0 0 2}$ \\
\hline $50,001-90,000$ & Mean & 0.00 & 0.00 & 0.00 \\
& $\mathrm{~N}$ & 3 & 3 & 3 \\
& Std. Deviation & $\mathbf{0 . 0 0 0}$ & $\mathbf{0 . 0 0 0}$ & $\mathbf{0 . 0 0 0}$ \\
\hline $90,001-130,000$ & Mean & 3.00 & 0.00 & 0.00 \\
& N & 8 & 8 & 8 \\
& Std. Deviation & $\mathbf{0 . 0 0 0}$ & $\mathbf{0 . 0 0 0}$ & $\mathbf{0 . 0 0 0}$ \\
\hline Total & Mean & 3.01 & 2.20 & 2.87 \\
& N & 340 & 340 & 340 \\
\hline Average Std. Deviation & Std. Deviation & $\mathbf{3 . 7 9}$ & $\mathbf{3 . 2 9}$ & $\mathbf{2 . 5 1}$ \\
\hline
\end{tabular}

\subsubsection{Influence of Age on Crop productivity (AG)}

The age of the famers was used to evaluate the effect of age on crop productivity Table 11. According to Shafiq \& Rehman (2000), the age of a farmer is expected to have a positive or a negative relationship with crop production outputs and the management in general. This means that younger farmers can be more active in carrying out their farming operations including farm management than the older farmers. It is possible that older farmers may be traditional and conservative to change and thus show less willingness to adopt new changing technology aimed at increasing productivity. 
International Journal of Research in Social Science and Humanities (IJRSS), Vol .1(5), Nov-Dec - 2020

Table 11: Influence of Age of the Respondents on Crop productivity

\begin{tabular}{|c|c|c|c|c|}
\hline \multicolumn{5}{|c|}{ Maize } \\
\hline \multicolumn{2}{|l|}{ Age of the respondent } & Productivity & Rice Productivity & Kales Productivity \\
\hline \multirow[t]{3}{*}{$18-35$ years } & Mean & 3.12 & 1.37 & 3.12 \\
\hline & $\mathrm{N}$ & 127 & 127 & 127 \\
\hline & Std. Deviation & 5.512 & 2.986 & 8.746 \\
\hline \multirow[t]{3}{*}{$36-55$ years } & Mean & 9.31 & 9.33 & 12.48 \\
\hline & $\mathrm{N}$ & 170 & 170 & 170 \\
\hline & Std. Deviation & 77.779 & 74.513 & 108.069 \\
\hline \multirow[t]{3}{*}{ 56-69 years } & Mean & 1.14 & 0.56 & 0.25 \\
\hline & $\mathrm{N}$ & 29 & 29 & 29 \\
\hline & Std. Deviation & 0.433 & 2.451 & 0.620 \\
\hline \multirow[t]{3}{*}{ Over 70 years } & Mean & 0.81 & 0.75 & 0.30 \\
\hline & $\mathrm{N}$ & 14 & 14 & 14 \\
\hline & Std. Deviation & 0.732 & 1.804 & 0.722 \\
\hline \multirow[t]{3}{*}{ Total } & Mean & 5.95 & 5.25 & 7.44 \\
\hline & $\mathrm{N}$ & 340 & 340 & 340 \\
\hline & Std. Deviation & 0.833 & 1.451 & 0.420 \\
\hline Average Std. Deviation & & & & 0.90 \\
\hline
\end{tabular}

\subsubsection{Influence of Education Level on Crop Productivity (ELR)}

The education level of the respondents were of sought to determine the importance and influence of education on crop production. It's common knowledge that, farmers with better education stand at a better chance of accessing irrigation information and apply them where necessary and are generally better able to assimilate, to process and to use this information (Taylor, 1997). The number of years when a person spent in formal education is one of the most critical determinants of increased household food production and adoption of good irrigation management. Further, education facilitates the process of information flow and leads persons to explore as wide as possible on the different pathways of acquiring information regarding emerging new technologies (Ersado, 2001). Following this observations the data was analyzed inferentially against crop productivity and their standard deviation determined as tabulated in Table 12.

These findings is consistent with a study by (Voh 1979; Chitere \& Dourer, 1985) who found out that in their studies that level education was an important factor when it comes to facilitating farmers' awareness in adoption new agricultural technologies. However, the study disagree with that of Chikwendu et al, (1996) who established that level of education andinformation access isinsignificant does not influence adoption of newtechnologies for crop production. 
International Journal of Research in Social Science and Humanities (IJRSS), Vol .1(5), Nov-Dec - 2020

Table 12: Influence of Education level of the Respondents on Crop productivity

\begin{tabular}{|c|c|c|c|c|}
\hline Education level & & $\begin{array}{l}\text { Maize } \\
\text { Productivity }\end{array}$ & Rice Productivity & Kales Productivity \\
\hline \multirow[t]{3}{*}{ None/illiterate } & Mean & 3.00 & 1.45 & 3.05 \\
\hline & $\mathrm{N}$ & 11 & 11 & 11 \\
\hline & Std. Deviation & 5.731 & 3.078 & 8.968 \\
\hline \multirow[t]{3}{*}{ Primary Education } & Mean & 1.72 & 1.34 & 1.72 \\
\hline & $\mathrm{N}$ & 82 & 82 & 82 \\
\hline & Std. Deviation & 3.680 & 2.486 & 5.618 \\
\hline \multirow[t]{3}{*}{ Secondary Education } & Mean & 6.78 & 6.42 & 8.81 \\
\hline & $\mathrm{N}$ & 135 & 135 & 135 \\
\hline & Std. Deviation & 61.933 & 59.321 & 86.095 \\
\hline \multirow[t]{3}{*}{ Middle level college } & Mean & 1.80 & 0.94 & 1.24 \\
\hline & $\mathrm{N}$ & 77 & 77 & 77 \\
\hline & Std. Deviation & 4.203 & 3.022 & 2.789 \\
\hline \multirow[t]{3}{*}{ University Education } & Mean & 2.21 & 0.93 & 2.05 \\
\hline & $\mathrm{N}$ & 34 & 34 & 34 \\
\hline & Std. Deviation & 4.574 & 2.546 & 7.125 \\
\hline \multirow[t]{3}{*}{ Total } & Mean & 5.95 & 5.25 & 7.44 \\
\hline & $\mathrm{N}$ & 340 & 340 & 340 \\
\hline & Std. Deviation & 3.203 & 2.022 & 4.789 \\
\hline Average Std. Deviation & & & & 3.34 \\
\hline
\end{tabular}

\subsection{Paired Sample t-test of Socio-Economic Factors on Crop Productivity}

The multiple regression analysis and ANOVA based on paired sample t-test was employed in analyzing the data inferentially. For the paired sample statistics, all the identified measures that believed to have an influence to crop productivity including but not limited to Attitude towards introduction of irrigation technologies (ATT), Irrigation technologies (IRT), Gender participation (GP), Monthly Household Income of the respondents (HI), Age of the respondents (AR) andEducation level of the respondents (ELR) were paired and analyzed against the dependent variable which was crop productivity and farming systems and their standard deviation determined as shown in Table 13.

Table13: Paired Samples Statistics (t-test)

\begin{tabular}{llcccc}
\hline PAIR & & Mean & N & Std. Deviation & Std. Error Mean \\
\hline Pair 1 & Crop Productivity \& Farming system & 6.14 & 326 & 56.294 & 3.118 \\
& ATT & $\mathbf{1 . 0 0}$ & $\mathbf{3 2 6}$ & $\mathbf{0 . 0 3}$ & $\mathbf{0 . 0 0 0}$ \\
Pair 2 & Crop Productivity \& Farming system & 6.14 & 326 & 56.294 & 3.118 \\
& IRT & $\mathbf{1 . 3 1}$ & $\mathbf{3 2 6}$ & $\mathbf{1 . 7 0}$ & $\mathbf{0 . 0 3 6}$ \\
Pair 3 & Crop Productivity \& Farming system & 6.14 & 326 & 56.294 & 3.118 \\
& GP & $\mathbf{1 . 1 0}$ & $\mathbf{3 2 6}$ & $\mathbf{6 1 . 5 3}$ & $\mathbf{0 . 0 1 9}$ \\
Pair 4 & Crop Productivity \& Farming system & 5.95 & 340 & 55.127 & 2.990 \\
& HI & $\mathbf{1 . 1 0}$ & $\mathbf{3 4 0}$ & $\mathbf{3 . 2 0}$ & $\mathbf{0 . 0 1 6}$ \\
Pair 5 & Crop Productivity \& Farming system & 5.95 & 340 & 55.127 & 2.990 \\
& AG & $\mathbf{1 . 1 0}$ & $\mathbf{3 4 0}$ & $\mathbf{0 . 9 0}$ & $\mathbf{0 . 0 1 6}$ \\
Pair 6 & Crop Productivity \& Farming system & 5.95 & 340 & 55.127 & 2.990 \\
& ELR & $\mathbf{1 . 1 0}$ & $\mathbf{3 4 0}$ & $\mathbf{3 . 3 4}$ & $\mathbf{0 . 0 1 6}$ \\
\hline
\end{tabular}




\subsection{Relationship between the Social-Economic Factors and Crop Productivity}

The general objective of this study was to assess the impact of irrigation technologies promoted through project extension approach on farming system and crop productivity among Kimira-Oluch smallholder farmers in Homa Bay County. A multiple regression analysis that relates dependent variables and identified independent variables were summarized and their results tabulated in Table 14.

The model summary in Table 14 indicates an absolute value of correlation coefficient of 0.823 which indicates that there is a high correlation between the dependent and the independent variables of crop productivity and selected socio-economic factors that is ATT, IRT, GP, HI, AR and ELR. The proportionate variation of the model was found to be $\mathrm{R}^{2}=0.714$, meaning that, the independent variables in the model can predict $71.4 \%$ of crop productivity (depended variable) and the other variables not included in the model can only predict $29.6 \%$ of crop productivity.

Table 15 shows the analysis of variance (ANOVA) result. The findings revealed that the regression model predicts that there is a significant improvement in productivity and farming system as well. This was revealed by $\mathrm{F}=71.83$ indicating significance relationship at $p$-value of $=0.000$.

The study was based on the regression analysis model shown below:

$\operatorname{Productivity}(\boldsymbol{Y})=\boldsymbol{a}_{\boldsymbol{0}}+\beta_{1} \mathrm{ATT}+\beta_{2} I R T+\beta_{3} \mathrm{GP}+\beta_{4} \mathrm{HI}+\beta_{5} \mathrm{AR}+\beta_{6} E L R+\boldsymbol{\varepsilon}$

Where:

$\boldsymbol{a}_{0}=$ Constant term which was 67.771

$\mathbf{X}_{\mathbf{1}}=$ linear sensitivity of Attitude (ATT) was -0.176

$\mathbf{X}_{\mathbf{2}}=$ linear sensitivity of Irrigation technologies (IRT) was 1.978

$\mathbf{X}_{\mathbf{3}}=$ linear sensitivity of Gender participation (GP) was 6.748

$\mathbf{X}_{\mathbf{4}}=$ linear sensitivity of Monthly Household Income of the respondents (HI) was 5.967

$\mathbf{X}_{\mathbf{5}}=$ linear sensitivity of Age of the respondents (AR) is 1.735

$\mathbf{X}_{\mathbf{6}}=$ linear sensitivity of Education level of the respondents (ELR) was 8.231

$\boldsymbol{\varepsilon}=$ is the marginal error usually assumed to be normally distributed.

By substituting the above values drawn from Table 16, the regression analysis model was concluded as:

$\operatorname{Productivity}(\boldsymbol{Y})=67.771-\mathbf{0 . 1 7 6} \mathbf{X}_{1}+1.978 \mathbf{X}_{\mathbf{2}}+6.748 \mathbf{X}_{\mathbf{3}}-5.967 \mathbf{X}_{\mathbf{4}}+1.735 \mathbf{X}_{\mathbf{5}}+8.231 \mathbf{X}_{\mathbf{6}}+\boldsymbol{\varepsilon}$

Table 14: Model Summary

\begin{tabular}{lc}
\hline Multiple R & 0.287 \\
R Square & 0.823 \\
Adjusted R Square & 0.714 \\
Std. Error of the Estimate & 5.426 \\
\hline
\end{tabular}

a. Predictors: (Constant), ATT, IRT,GP,HI,AR,ELR

Table 15: ANOVA

\begin{tabular}{llllll}
\hline & Sum of Squares & df & Mean Square & F & Sig. \\
\hline Regression & 84.608 & 4 & 21.152 & 71.83 & 0.000 \\
Residual & 94.531 & 321 & 2.944 & & \\
Total & 179.139 & 325 & & & \\
\hline
\end{tabular}

a. Predictors: (Constant), ATT, IRT,GP,HI,AR,ELR

b. Dependent Variable: PRODUCTIVITY 
International Journal of Research in Social Science and Humanities (IJRSS), Vol .1(5), Nov-Dec - 2020

Table 16: Correlation Coefficients

\begin{tabular}{|c|c|c|c|c|c|}
\hline & \multicolumn{2}{|c|}{ Unstandardized Coefficients } & \multirow[b]{2}{*}{ Beta } & \multirow[b]{2}{*}{$\mathbf{t}$} & \multirow[b]{2}{*}{ Sig. } \\
\hline & $\overline{\mathbf{B}}$ & Std. Error & & & \\
\hline (CONSTANT) & 67.771 & 27.769 & - & -2.441 & 0.015 \\
\hline ATT & -0.176 & 0.000 & -0.005 & -0.080 & 0.965 \\
\hline IRT & 1.978 & 0.036 & 0.485 & 5.393 & 0.000 \\
\hline GP & 6.748 & 0.019 & 0.253 & 2.783 & 0.046 \\
\hline HI & 5.967 & 0.016 & 0.582 & -2.531 & 0.000 \\
\hline $\mathbf{A R}$ & 1.735 & 0.016 & 0.037 & 0.641 & 0.052 \\
\hline ELR & 8.231 & 0.016 & 0.472 & 5.757 & 0.000 \\
\hline
\end{tabular}

\section{CONCLUSION}

From the above generated equation, the findings showed that the constant term obtained was 67.771 ; the coefficient for Irrigation technologies was 1.978, the coefficient of Gender participation was 6.748 while that of Household Income of the respondents was found to be 5.967, that of Age of the respondents was found to be 1.735 and finally that of Education level of the respondents was 8.231. However, the coefficient for farmers' attitude obtained was negative -0.176 . This means that, all those socio-economic variables tested positive had influence on the productivity except that farmers' attitude which exhibited negative and had no significant influence on productivity. The result was further confirmed by correlation coefficients in Table 16 that all the measures of selected socio-economic factors exhibited significant relationships of p-value of $0.000,0.046,0.000,0.052$ and 0.000 for Irrigation technologies (IRT), Gender participation (GP), Monthly Household Income of the respondents (HI), Age of the respondents (AR) and Education level of the respondents (ELR) respectively expect for attitude (ATT) which was insignificant at p-value of 0.965 . Thus the null hypothesis that the selected socio-economic factors do not have statistically significant influence on crop productivity is rejected.

\section{ACKNOWLEDGEMENT}

This research received great support from a number of people who I am grateful to and remain indebted to. I would like to acknowledge Prof. Basweti, Prof Maobe and Dr. Bunyatta with warm gratitude for their immense guidance and constructive criticisms in coming up with this paper may God bless you for your good work. Secondly, is to express my deepest gratitude from the bottom of my heart to Kisii University and all my course work lecturers for their inspiration and insights throughout the course work as well as their valuable guideline and unique encouragement.Thirdly, is to thank the African Development Bank (ADB) for granting me full scholarship to pursue my $\mathrm{PhD}$ in this renowned University. I also extend my heartfelt thank to the Ministry of Agriculture, Livestock and Fisheries and all the farmers of Kimira and Oluch scheme who took their time in answering questions as per the interview schedule and interview schedules with creditable information.

\section{REFERENCES}

Adetola I. Adeoti (2009) Factors Influencing Irrigation Technology Adoption and its Impact on Household Poverty in Ghana. Journal of Agriculture and Rural Development in the Tropics and Subtropics. Volume 109, No. 1 pages 51-63

Ahmed, E., and Sulaiman, J., and Saidatulakm, M. (2012).Factors influencing Farmers' Treatments to Use Irrigation Water. Resources and Environment, 2(2), 73-81. doi:10.5923/j.re.20120202.11.

Amao, J. O. \&Awoyemi, T. T. (2008) Adoption of improved cassava varieties and its welfareeffect on producing households in Osogbo ADP zone of Osun state.Retrieved on 25 June 2012 from www.geneconserve.pro.br/artigo045.pdf

Ariga, J., Jayne, T.S., Kibaara, B., \&Nyoro, J.K. (2009).Trends and patterns in fertilizer useby smallholder farmers in Kenya, 1997-2007. Tegemeo Institute of Agricultural Policy and Development, Egerton University

Briggeman, B.C. (2011). The importance of off-farm income to servicing farm debt.FederalReserve Bank of Kansas City. Retrieved on 20 June 2012 from www.KansasCityFed.org

Burrow, C. (1987). Water Resources and Agricultural Development In The Topics: New York,John Wiley And Sons.

Calatrava-Leyva, J., Franco, J. A., and Gonzalez-Roa, M. C. (2005).Adoption of soil conservation practices in olive groves: The case of Spanish mountainous areas. Presented at the XI International Congress of the European Association of Agricultural Economists, Denmark 
International Journal of Research in Social Science and Humanities (IJRSS), Vol .1(5), Nov-Dec - 2020

Chebil, A., Frija, A., and Abdelkafi, B. (2012). Irrigation water use efficiency in collective irrigated schemes of Tunisia: Determinants and potential irrigation cost reduction. Agricultural Economics Review, 13(1).

Chikwendu, D.O (1996). Adoption of improved technologies for millet productionby farmers in Borno State of Nigeria. Samaru Journal of Agricultural Research, 13, 73-81.

Chitere, P.A. (1985). Agro frestry Plots for Rural Kenya Project.Socio-Economic Survey Report. Mazingira Institute, Nairobi, Kenya

DanielZiba (2015), The Impact of Irrigation Schemes on Farmers' Income and Livelihoods in the Upper East Region Of Ghana Unpublished Msc. Thesis Kwame Nkrumah University of Science And Technology.

Ellis-O’Quinn, A. (2012). An Ex Post Facto Study of First-Year Student Orientation as an Indicator of Student Success at a Community College.Inquiry, 17(1), 51-57.

FAO. (2000). Socio-economic impact of smallholder irrigation development in Zimbabwe: case studies of ten irrigation schemes.

FAO Sub-Regional Office for East and Southern Africa (SAFR), Harare, SAFR/AGLW/DOC/002.

FAO (2016).The Gender and Equity Implications of Land-Related Investments by Producer Organizations in Malawi. Rome, Italy. Accessed November 2020

IFAD (2012b).Gender and water. "Securing water for improved rural livelihoods: The multipleuses system approach.” IFAD, Rome.

Jansen, A., and Schulz, C. (2006).Water Demand and The Urban Poor: A Study of the Factors influencing Water Consumption among Households in Cape Town, South Africa (Working paper No. 02/06). Norway.

Janvry, A., Sadoulet, E., \& Zhu, N. (2005).The role of non-farm incomes in reducing ruralpoverty and inequality in China. Retrieved on November 2020.fromciteseerx.ist.psu.edu/viewdoc/download?doi=10.1.1.69.pdf

Karina F. Z. and Alex WambuaMwaniki (2011). Irrigation Agriculture in Kenya - Impact of the Economic Stimulus Programme and Long-term Prospects for Food Security in an Era of Climate Change, Heinrich BöllStiftung, East and Horn of Africa (1- 62)

KulshreshathaS.N \& Brown W.J (1993). Role of the farmers' attitude in adoption of irrigation in Saskatchewan. Journal of Irrigation and Drainage Systems (7) 85-98,

Kundlander, G., Groenewald, D., Baiphethi, M., \&Viljoen, M. (1994). Environmental Systems (Certificate Course) Bulawayo ,Tyrocrafters Press.

Mendola, M. (2005). Agricultural technology and poverty reduction: A micro-level analysis of causal effects. Working Paper No 14. Milan, Italy: University of Milan and Centro Studi L. d'Agliano.

Michael MusyokiMuthui (2015). Socio-Economic and Adminstrative Factors InfluencingAdoption of Irrigation Technology in TharakaNithi County. Unpublished Msc Thesis, University of Nairobi Press

Mugenda, Olive M. \&Mugenda, Abel G. (2003).Research Methods: Quantitative and Qualitative Approaches, Acts Press, Nairobi-Kenya

Owilla, B. P. (2010). Analysis of economic efficiency of irrigation water-use in Mwea irrigation scheme, Kirinyaga District, Kenya (Master's Thesis).Kenyatta University, Nairobi, Kenya Ramirez et al., 2008).

Rockaway, D. T., Coomes, P. A., Rivard, J., and Kornstein, B. (2011). Residential water use trends in North America. Journal of $A W W A, 103(2)$.

Upadhyay, B (2004) Gender aspects of smallholder irrigation technology: Insights from Nepal. Journal of Applied Irrigation Science, Vol. 39. No 2/2004, pp. 315-327

Waithaka, M.M., Thornton, P.K., Shepherd, K.D. and Ndiwa, N.N. (2007). Factors affectingthe use of fertilizers and manure by smallholders: the case of Vihiga, western Kenya. NutrCyclAgroecosyst 78:211-224 